\title{
Atherosclerosis and the Hydrogen Sulfide Signaling Pathway - Therapeutic Approaches to Disease Prevention
}

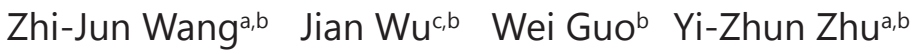 \\ aSchool of Pharmacy and State Key Laboratory of Quality Research in Chinese Medicine, Macau \\ University of Science \& Technology, Macau, 'SShanghai Key Laboratory of Bioactive Small Molecules, \\ Department of Pharmacology, School of Pharmacy, Fudan University, Shanghai, 'Department of \\ Pharmacy, Huashan Hospital, Fudan University, Shanghai, China
}

\section{Key Words \\ $\mathrm{H}_{2} \mathrm{~S} \cdot$ Atherosclerosis $\bullet \mathrm{CSE} \cdot \mathrm{ApoE} \cdot$ Gasotransmitter}

\begin{abstract}
Hydrogen sulfide $\left(\mathrm{H}_{2} \mathrm{~S}\right)$ is now admitted as a third gasotransmitter together with nitric oxide (NO) and carbon monoxide (CO), albeit it was originally considered as a foul and poisonous gas. Endogenous $\mathrm{H}_{2} \mathrm{~S}$ production in mammalian cells is counting on the three enzymes acting on cysteine. Involvement of $\mathrm{H}_{2} \mathrm{~S}$ in various physiological and pathological processes has been extensively studied in the last fifteen years. Mounting evidence suggests that $\mathrm{H}_{2} \mathrm{~S}$ is able to protect against atherosclerosis development and progression. Exogenous $\mathrm{H}_{2} \mathrm{~S}$ supplement has salutary effects on atherogenesis, and reduction of the endogenous $\mathrm{H}_{2} \mathrm{~S}$ level accelerates atherosclerosis. The anti-atherosclerotic mechanisms of $\mathrm{H}_{2} \mathrm{~S}$ have been descried in different aspects, including endothelium preservation, antioxidative action, anti-inflammatory responses, vasorelaxation, regulation of ion channels, etc. However, further investigation is still needed to help us gain more insights into the fundamental underlying mechanisms, and that will allow us to design better therapeutic applications of $\mathrm{H}_{2} \mathrm{~S}$ in the treatment of atherosclerosis.
\end{abstract}

\section{Introduction}

(C) 2017 The Author(s)

Published by S. Karger AG, Basel

$\mathrm{H}_{2} \mathrm{~S}$ made its landfall in gasotransmitter field 15 years ago [1], being recognized as the third gasotransmitter alongside with nitride oxide (NO) and carbon monoxide (CO). Like $\mathrm{NO}$ and $\mathrm{CO}, \mathrm{H}_{2} \mathrm{~S}$ is widely implicated in the physiological and pathophysiological processes in both prokaryotes and eukaryotes. It is known that these anaerobic gases ubiquitously existed and may serve as an energy source in the ancient earth where considering amount of oxygen was available. So it is reasonable that these three gasotransmitters profoundly affect

Z. Wang and J. Wu contributed equally to this work.

Yi-Zhun Zhu and Wei Guo

Department of Pharmacology, School of Pharmacy, Fudan University, 826 Zhangheng Road, Shanghai 201203 (China)

E-Mail zhuyz@fudan.edu.cn/yzzhu@must.edu.mo/guowei@fudan.edu.cn 
the lives on earth now since their entire involvement in our evolutionary process.

Atherosclerosis, characterized with fatty of cholesterol build up in the large- or medium-sized vessels and artery trees [2], is developed from a continuous process that involves numerous pathophysiological processes that influence each other. These include vascular inflammation, endothelial dysfunction, smooth muscle cell (SMC) proliferation and migration, lipoproteins accumulation monocyte recruitment and adhesion and macrophage differentiation. Since the precise roles of each of processes contributed to the disease are not fully understood, it's difficult to reveal drug targets and develop corresponding therapeutic approaches for intervention. Recently, it was reported that alteration of $\mathrm{H}_{2} \mathrm{~S}$ production is highly associated with atherosclerosis acceleration, and $\mathrm{H}_{2} \mathrm{~S}$ intervention could significantly prevent the emergence and progression of atherosclerosis which may become a whole new target for atherosclerosis treatment, drawing much of our attention now. But how $\mathrm{H}_{2} \mathrm{~S}$ exerts this beneficial effects haven't been fully elucidated.

In this review article, we discuss the endogenous production and elimination of $\mathrm{H}_{2} \mathrm{~S}$, with its usual physiological actions and mechanisms related to vasculature, and how $\mathrm{H}_{2} \mathrm{~S}$ participates in atherosclerosis development.

\section{$\mathrm{H}_{2} \mathrm{~S}$ production and elimination}

The production of $\mathrm{H}_{2} \mathrm{~S}$ in mammalian cells is constitutive of both endogenous enzyme catalysis and nonenzymatic pathways (e.g., degradation of thiols and thiol-containing molecules). However, more studies are focusing on the enzymatic generation of $\mathrm{H}_{2} \mathrm{~S}$, which may be crucial for the regulation in specific cells under special conditions. $\mathrm{H}_{2} \mathrm{~S}$ generated from molecule reservoirs with bound sulfane sulfur by enzymes can interact with cysteine thiols to form stabilized persulfides which may be one of the mechanisms by shedding light on the protective effects of the gas.

As to enzymatic pathways of generating $\mathrm{H}_{2} \mathrm{~S}$, four critical enzymes are required, including cystathionine $\gamma$ lyase (CSE, EC 4.4.1.1), cystathionine $\beta$ synthase (CBS, EC 4.2.1.22), cysteine aminotransferase (CAT, EC2.6.1.3) and 3-mercaptopryruvate sulfurtransferase (3-MST, EC 2.8.1.2). These four enzymes compose three chemical pathways to generate $\mathrm{H}_{2} \mathrm{~S}$ in mammalian cells. CSE, which is normally localized in cytosol catalyzes L-cysteine to thiocysteine and then rearranges to form $\mathrm{H}_{2} \mathrm{~S}$. CBS acts on L-cysteine to generate $\mathrm{H}_{2} \mathrm{~S}$ and L-serine. In addition, CBS is the rate-limiting enzyme to consume homocysteine and serine to train cystathionine. 3-mercaptopyruvate is produced by CAT with L-cysteine and keto acids and is then catalyzed by 3-MST to form $\mathrm{H}_{2} \mathrm{~S}$. Additionally, it is useful to mention that cysteinelyase (CL, EC 4.4.1.10) can convert $L$-cysteine and sulfite into cysteate and $\mathrm{H}_{2} \mathrm{~S}$, contributing to part of endogenous $\mathrm{H}_{2} \mathrm{~S}$ production. Recent researches reported a novel pathway to produce $\mathrm{H}_{2} \mathrm{~S}$ by utilizing $D$-cysteine, which introduced a new enzyme named D-amino acid oxidase (DAO, EC 1.4.3.3). DAO metabolizes $D$-Cysteine to achiral 3-mercaptopyruvate which is a substrate of 3-MST to produce $\mathrm{H}_{2} \mathrm{~S}$ [3]. Interestingly, DAO is localized in peroxisomer, whereas 3-MST is located at mitochondria and DAO is only found in brain and kidney, which limits the effects of DAO/3MST pathway, whereas the $\mathrm{H}_{2} \mathrm{~S}$ concentration is 7- and 80-fold higher in cerebellum and kidney than that in other tissues, which may indicate significance of $\mathrm{H}_{2} \mathrm{~S}$ in related regions [4]. Pyridoxal 5'-phosphate (PPP) is requisite for CSE, CBS, CAT and CL as a cofactor, but 3-MST is zinc dependent. The elimination of $\mathrm{H}_{2} \mathrm{~S}$ is constitutive of oxidation, methylation, scavenging together with expiration and excretion. Specific catalytic reaction pathways can be transmitted to Fig. 1.

Distribution of endogenous $\mathrm{H}_{2} \mathrm{~S}$ producing enzymes in mammalian tissues is complicated. CSE is generally located in cardiovascular system [5], liver [6], kidney [7] and gastrointestinal tract [8-10]. CBS protein expression is dominant in the brain [11], and its existence in other tissue has been confirmed (e.g., liver, kidney, uterus and gastrointestinal tract [12-14]). 3-MST is detected mostly in the central nervous system [15], other tissues include vasculature [16], especially coronary artery [17], kidney and liver [15, 18]. 


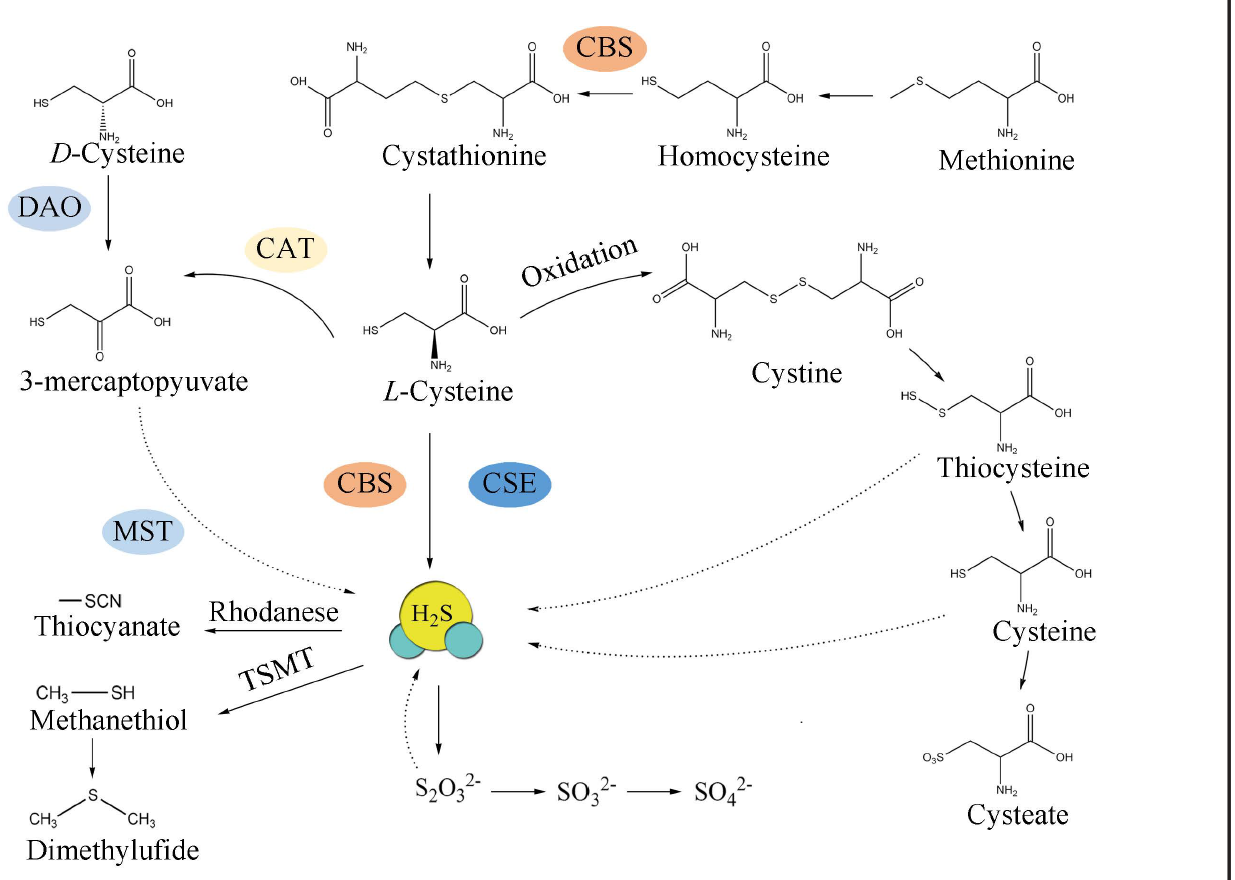

Fig. 1. Mammalian metabolic pathways involved in $\mathrm{H}_{2} \mathrm{~S}$ biosynthesis and catabolism.

\section{Physiological effects of $\mathrm{H}_{2} \mathrm{~S}$ and related molecular mechanisms associated with atherosclerosis preventing effect}

$\mathrm{H}_{2} \mathrm{~S}$ exerts distinct physiological effects on different organs and tissues, varying from heart to brain and from vasculature to neurons. In consideration of the chemical nature of $\mathrm{H}_{2} \mathrm{~S}$, it can easily reach its molecular targets since $\mathrm{H}_{2} \mathrm{~S}$ is a gasotransmitter which are dissolved in extracellular fluid, on the plasma membrane, within the cytosol or inside the intracellular organelles, mirroring its wide scope of physiological and biological effects. However, this peculiar chemical reactive ability with certain types of molecular targets that make it as a selective and multifunctional signaling molecule [19].

\section{Interactions with ion channels}

$\mathrm{H}_{2} \mathrm{~S}$, as an endothelium-derived hyperpolarizing factor (EDHF) being recently identified, exerts vasorelaxant effects by influencing many ion channels, partially explained by sulfhydrating vasorelaxation related ion channels [20]. To date, it activates small- and intermediate-conductance calcium-activate potassium channels $\left(\mathrm{SK}_{\mathrm{Ca}}\right.$ and $\mathrm{IK}_{\mathrm{Ca}}$ channels, respectively) and induces endothelium-dependent smooth muscle hyperpolarization, which can be stopped by the co-application of charybdotoxin and apamin [21]. The mechanism of $\mathrm{H}_{2} \mathrm{~S}$ playing a role as an EDHF is partly elucidated by $\mathrm{H}_{2} \mathrm{~S}$ sulfhydrating $\mathrm{IK}_{\mathrm{Ca}}$ channels in primary human aortic endothelial cells [20]. Not limiting to $\mathrm{SK}_{\mathrm{Ca}}$ and $\mathrm{IK}_{\mathrm{Ca}}$ channels, it has been reported that $\mathrm{H}_{2} \mathrm{~S}$ dilates phenylephrine (PE)-constricted rat mesenteric arteries by activating endothelial big-conductance calcium-activated potassium channels $\left(\mathrm{BK}_{\mathrm{Ca}}\right)$ [22] and CYP2C and then triggers vascular smooth muscle cells (VSMCs) $\mathrm{Ca}^{2+}$ sparks, which can be inhibited by ryanodine (ryanodine receptor blocker), iberiotoxin ( $\mathrm{BK}_{\mathrm{Ca}}$ blocker), endothelium denudation and sulfaphenazole (CYP2C inhibitor) [23].

Besides conductance calcium activated potassium channels, $\mathrm{H}_{2} \mathrm{~S}$ also activates ATPsensitive potassium channels ( $\mathrm{K}_{\text {ATP }}$ channels) to mediate $\mathrm{H}_{2} \mathrm{~S}$-evoked vasodilation [5]. The stimulation of $\mathrm{K}_{\text {ATP }}$ channels in VSMC partially demonstrates the vasorelaxant effects of $\mathrm{H}_{2} \mathrm{~S}$ $[24,25]$. As the molecular target of $\mathrm{H}_{2} \mathrm{~S}$, the sulfonylurea receptor 1 (SUR1) subunit of $\mathrm{K}_{\mathrm{ATP}}$ 
channels through mutagenesis in HEK-293 cells [26] and the SUR2B subunit of $\mathrm{K}_{\text {ATP }}$ channels in colonic smooth muscle cells [27] can be sulfhydrated by $\mathrm{H}_{2} \mathrm{~S}$. $\mathrm{K}_{\text {ATP }}$ channels, 4-Aminopyridine (4-AP)-sensitive potassium channels are also contributed to NaHS-induced relaxation in rat coronary artery [28]. Besides, $\mathrm{H}_{2} \mathrm{~S}$ mediates rat mesenteric arteries vasorelaxation through the release of neurotransmitters by sensory nerves' transient receptor potential ankyrin 1 (TRPA1) channels activation [29].

$\mathrm{H}_{2} \mathrm{~S}$ plays synergistically with $\mathrm{NO}$ to form polysulfides $\left(\mathrm{H}_{2} \mathrm{~S}_{\mathrm{n}}\right)$ to act as TRPA1 channel activator in vasodilation [30]. Meanwhile, ZYZ-803, a slow-releasing $\mathrm{H}_{2} \mathrm{~S}-\mathrm{NO}$ hybrid molecule, could exert vasorelaxant effect [31] and angiogenesis [32] activity better than S-Propargyl-Cysteine (SPRC) and furoxan alone or together. And as reported recently, $\mathrm{H}_{2} \mathrm{~S}$ could upregulate and stabilize the endothelial nitric oxide synthase by facilitating miRNA455-3p expression [33]. And $\mathrm{H}_{2} \mathrm{~S}$ could down regulate inducible NOS (iNOS) expression in LPS-induced acute lung injury [34].

\section{Interactions with second messengers}

Considering the wide scope of influence of $\mathrm{H}_{2} \mathrm{~S}$, inevitably $\mathrm{H}_{2} \mathrm{~S}$ affects second messengers although it can also directly affect the target protein alone. Cytosol free calcium is a classical second messenger in cellular signal transduction. Effects of $\mathrm{H}_{2} \mathrm{~S}$ on calcium handling in specific cells differ. In endothelial cells, $\mathrm{H}_{2} \mathrm{~S}$ can raise intracellular calcium levels by either triggering calcium influx [35] or stimulating an ATP- and 4-CEP sensitive intracellular calcium pool [36], thus activating many calcium-dependent signaling pathways such as endothelial cells migration [37] and metabolism or adjusted function ensuing. $\mathrm{H}_{2} \mathrm{~S}$ triggers calcium sparks in VSMCs in rat mesenteric arteries [23] and pig cerebral arterioles [38]. Calcium sparks stimulate transient $\mathrm{K}_{\mathrm{Ca}}$ channels and consequent plasma membrane hyperpolarization which concretely manifests vasodilation. Actions on cardiomyocytes of $\mathrm{H}_{2} \mathrm{~S}$ are biphasic, not only inhibiting L-type and T-type VDCCs but also increasing calcium release from intracellular calcium pool [39], of which the realistic functional consequence has not been clarified. In turn, calcium-sensing receptor (CaSR) regulates the endogenous $\mathrm{CSE} / \mathrm{H}_{2} \mathrm{~S}$ pathway to achieve the inhibition of proliferation of VSMCs in diabetic models [40] and the protective effects in high glucose-induced cardiotoxicity via inhibition of nucleotide-binding domain, leucine-rich-containing family, pyrin domaincontaining-3 (NLRP3) inflammasome activation [41] and NADPH oxidase 4 (NOX4) inhibition [42].

Besides, $\mathrm{H}_{2} \mathrm{~S}$ inhibits adenylyl cyclase and stimulates phosphodiesterases (PDEs) to make the concentration of cyclic AMP decline [43]. However, it has been reported that $\mathrm{H}_{2} \mathrm{~S}$ inhibits PDEs in many studies $[44,45]$. How this contradiction occurs will raise the issue of whether the effect of $\mathrm{H}_{2} \mathrm{~S}$ is tissue specific.

\section{Post-translational modification : proteins sulfhydration}

Protein S-sulfhydration is ubiquitous in vivo. It has been reported that S-sulfhydration can be detected by biotin-switch assay [46] and tag-witch method [47, 48]. For instance, Kelch-lick ECH-associated protein 1 (KEAP1), a negative protein factor of nuclear factor erythroid 2-related factor 2 (NRF2), can be sulfhydrated at the Cys151, but not Cys273, by $\mathrm{H}_{2} \mathrm{~S}$ to dissociate with NRF2, hence, the NRF2-related antioxidant responses was enhanced $[49,50]$ and subsequent diabetes-accelerated atherosclerotic progress was ameliorated [51].

\section{$\mathrm{H}_{2} \mathrm{~S}$ and antioxidant defences}

Redox includes oxidation and reduction processes, where electrons migrate from the reductant to oxidant. Redox balance shift reflects the homeostasis change, more specifically, higher oxidant stress and/or lower reductive ability contributes to numerous pathological processes and molecule and cell damage. The antioxidant effects of $\mathrm{H}_{2} \mathrm{~S}$ have been clearly established, not only because of its reductive chemical nature, but also its ability of regulating lots of protein and signaling pathways [52]. $\mathrm{H}_{2} \mathrm{~S}$ destroys lipid hydroperoxides in oxidized low-density lipoprotein (ox-LDL) [53]. In addition to hydroperoxides, $\mathrm{H}_{2} \mathrm{~S}$ scavenges oxidants including superoxide [54], $\mathrm{H}_{2} \mathrm{O}_{2}, \mathrm{HOCl} / \mathrm{OCl}^{-}$and $\mathrm{ONOOH} / \mathrm{ONOO}^{-}$[55], although the 


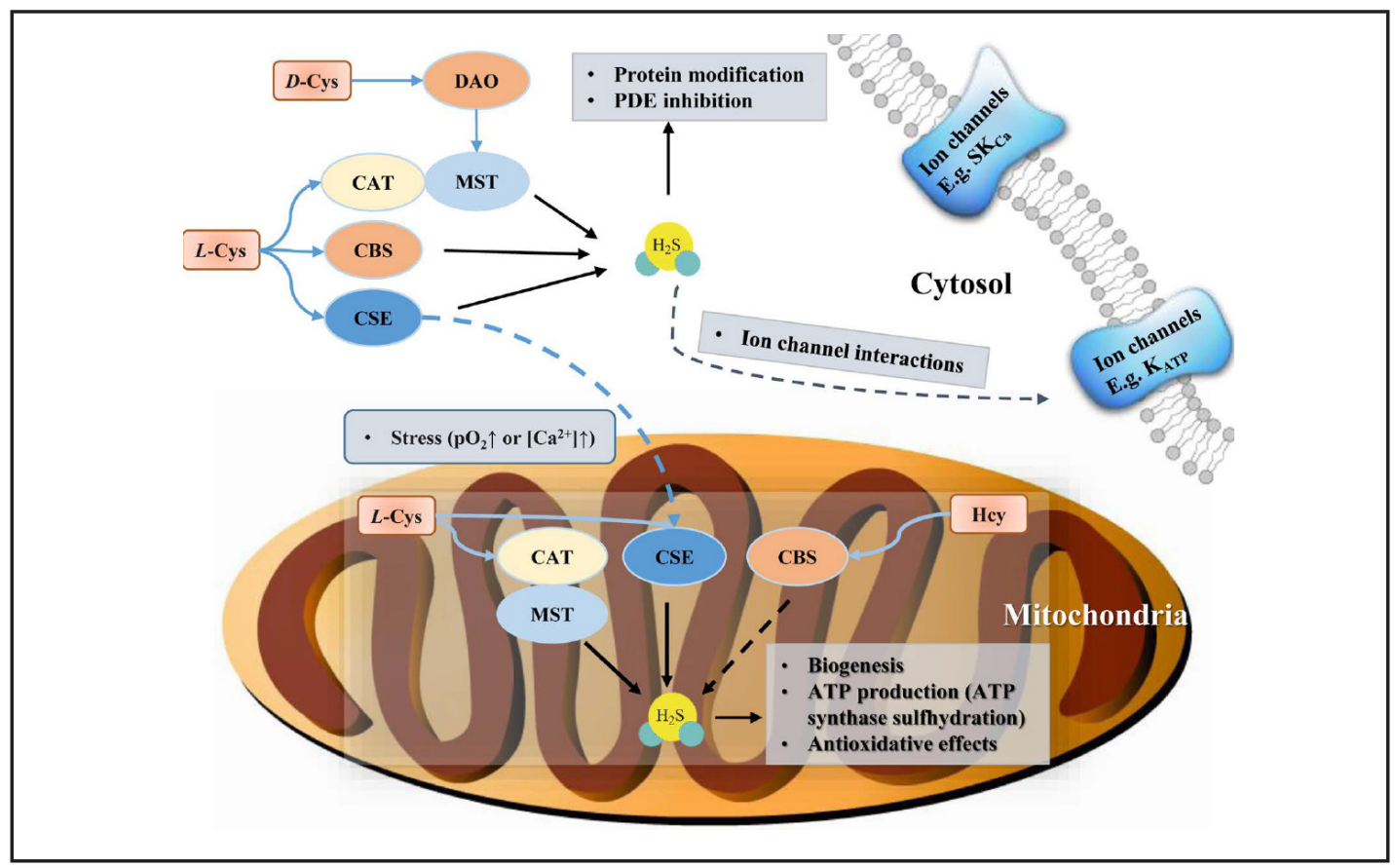

Fig. 2. Cystathionine $\gamma$ lyase and cystathionine $\beta$ synthase (CBS) use $L$-cysteine as the substrate to produce $\mathrm{H}_{2} \mathrm{~S}$ within mammalian tissues. In addition, 3-mercaptopyruvate sulfurtransferase (3-MST/MST) acts on 3-mercaptopyruvate (3-MP), produced by cysteine aminotransferase (CAT) from L-cysteine, to produce $\mathrm{H}_{2} \mathrm{~S}$. 3-MP can also synthesised from D-cysteine by the catalytic action of D-aminoacid oxidase (DAO). Interestingly, CSE is usually located within the cytosol however recent evidence suggests that this enzyme can also translocated to mitochondrion under stress conditions (e.g. $\mathrm{pO}_{2} \uparrow$ or $\left[\mathrm{Ca}^{2+} \uparrow\right.$ ). Both CAT and MST can be found both in cytosol and mitochondrion. CBS is mostly located in cytosol. Hcy, homocysteine; PDE, phosphodiesterase; $\mathrm{pO}_{2}$, partial pressure of oxygen.

low physiological concentration of $\mathrm{H}_{2} \mathrm{~S}$ can not fully account for the antioxidant effects of $\mathrm{H}_{2} \mathrm{~S}$ $[55,56]$, indicating another mechanism rather than its chemical redox nature plays a role in it. As to signaling pathway, KEAP1-NRF2 pathway S-sulfhydration [49] could serve as an example to modulate redox balance homeostasis. Schematic graph of $\mathrm{H}_{2} \mathrm{~S}$ related physical molecular mechanisms could be referred to Fig. 2 .

\section{$\mathrm{H}_{2} \mathrm{~S}$ epigenetic regulation is an important factor in the pathogenesis of atherosclerosis}

Sirtuin 1 (SIRT1) and $\mathrm{H}_{2} \mathrm{~S}$

Although evidence has been pointed to the direct actions of $\mathrm{H}_{2} \mathrm{~S}$ to hamper the development of atherosclerosis, whether other molecular mechanisms are involved in antiatherogenesis effect of $\mathrm{H}_{2} \mathrm{~S}$ is well worth considering. SIRT1, functions as a NAD ${ }^{+}$-dependent histone deacetylase, is highly distributed in the vasculature [57] and is implicated in the field of aging, metabolism [58]. Previous studies have demonstrated that SIRT1 played a major role in regulating the vascular tone [59-61] and down regulation of atherosclerosis [61, 62]. It has been reported that mice overexpression of SIRT1 preserved the endothelium function comparing with that of WT littermates fed with high-fat diet and overexpression of SITR1 in ApoE $\mathrm{E}^{-/-}$mice developed less atherosclerotic lesions compared with the ApoE ${ }^{-/}$controls [61]. The mechanism of SIRT1 improving atherosclerosis may include dilating arteries [59], preserving function of endothelium [60] and preventing endothelial senescence [63], downregulating neointima formation [64] and vascular modeling [65], decreasing Lox1-induced foam cell formation [62] and protecting against DNA damage [66]. It has been 
reported that $\mathrm{H}_{2} \mathrm{~S}$ upregulated SIRT1 to exert some of its protective effects. For example, $\mathrm{H}_{2} \mathrm{~S}$ upregulated SIRT1 to inhibit endoplasmic reticulum stress in PC12 cells [67] and to prevent $\mathrm{H}_{2} \mathrm{O}_{2}$-induced [68] or nicotinamide-induced [69] senescence in human umbilical vein endothelial cells (HUVECs). Besides HUVECs, previous studies from our group demonstrated that $\mathrm{H}_{2} \mathrm{~S}$ increased SIRT1 expression to abolish the oxidative stress induced apoptosis in H9c2 cardiomyocytes [70] and previous studies from our group demonstrated [6] found that $\mathrm{H}_{2} \mathrm{~S}$ attenuated inflammatory hepcidin partially by promoting SIRT1-mediated STAT3 deacetylation. SIRT3, one of the isoforms of SIRT family, has also been reported that it could be regulated by $\mathrm{H}_{2} \mathrm{~S}$ to protect endothelial cells in an antioxidant manner [71].

\section{DNA damage and $\mathrm{H}_{2} \mathrm{~S}$}

DNA damage accumulation is one of the notable features of atherosclerosis [72]. Mitochondrial DNA ( $m t D N A)$ damage has been reported as a risk factor independent of reactive oxygen species (ROS) to accelerate atherosclerosis by acing on VSMCs and monocytes [73]. In addition to mtDNA damage, VSMC DNA damage, including double-stranded breaks (DSBs) and DNA damage response activation, could alter plaque phenotype and inhibits fibrous cap areas, making it a novel target to exert salutary effects on plaque stability [74]. Interestingly, $\mathrm{H}_{2} \mathrm{~S}$ ameliorates DNA damage in endothelial cells and fibroblasts via S-sulfhydration of MEK1 which leads to activation of PARP-1, thus attenuating cell senescence [75]. Besides, $\mathrm{H}_{2} \mathrm{~S}$ maintains mtDNA replication and copy number by demethylation of mitochondrial transcription factor A (TFAM) [76]. Not limited to DNA itself, $\mathrm{H}_{2} \mathrm{~S}$ can also remodel chromatin to modulate cytokine production [77]. Interestingly, CSE gene promoter was methylated by ox-LDL treatment in macrophages and in ApoE KO mice, which was recently reported by Du et al. [78]. It will be an interesting question whether $\mathrm{H}_{2} \mathrm{~S}$ plays its anti-atherosclerotic role via repairing DNA both in nuclear and mitochondria. As to the role of VSMC in atherosclerosis, recently Feil [79] et al. reported that VSMC could transdifferentiate to macrophage-like cell during atherosclerosis, which had a significant effect of plaque stability because of loss of the balance of atherosclerotic composition. It will be just an question that whether any link exists between DNA damage, VSMC transdifferentiation and $\mathrm{H}_{2} \mathrm{~S}$. S-Propargyl-Cysteine (SPRC), an endogenous $\mathrm{H}_{2} \mathrm{~S}$ initiator derived from garlic, could ameliorate DNA damage in doxorubicin-induced cardiotoxicity [80]. Schematic figure of $\mathrm{H}_{2} \mathrm{~S}$-exerted therapeutic effects could be transmitted to Fig. 3 .

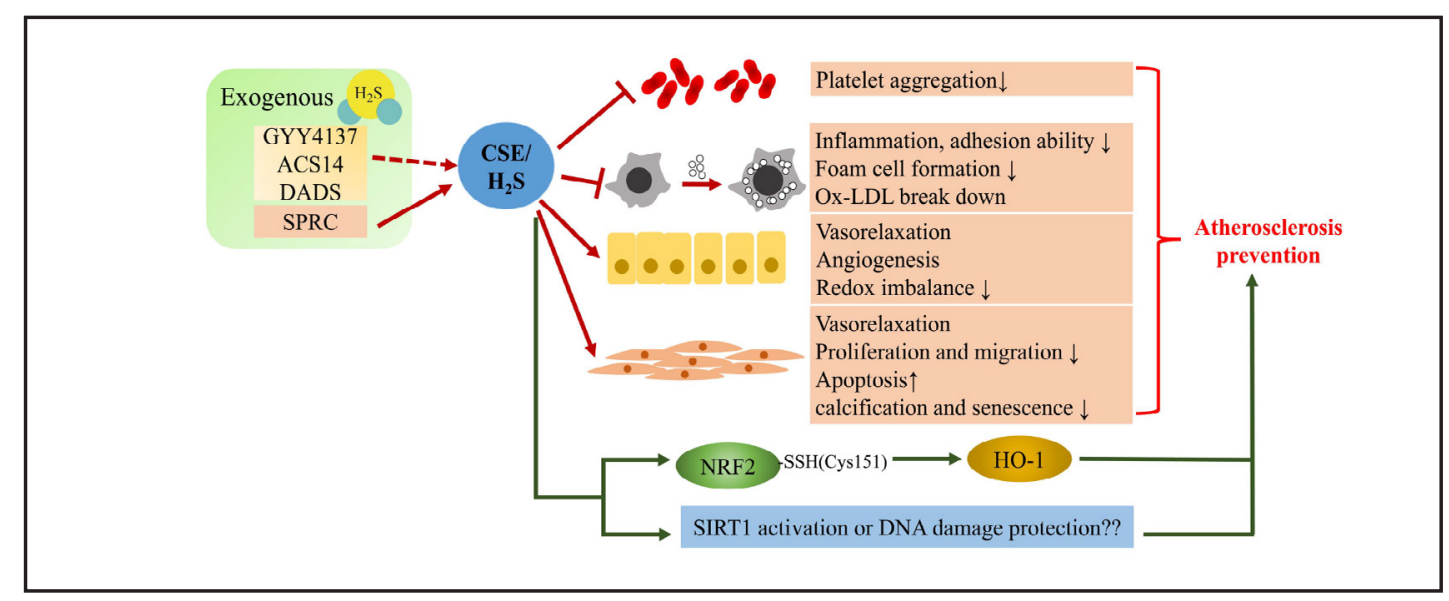

Fig. 3. Exogenous and endogenous $\mathrm{H}_{2} \mathrm{~S}$ can reduce the progression of atherosclerosis via amelioration of platelet aggregation, inhibition of inflammation, reduction of foam cell formation, vasorelaxation, and prevention of vascular smooth muscle cell (VSMC) proliferation, migration, calcification and senescence, and induction of VSMC apoptosis. These therapeutic effects are partly attributed to the S-sulfhydration at Cys151 of NRF2, which can trigger HO-1 upregulation and induce cellular antioxidative defences.

\section{KARGER}




\section{Evidence related to atherosclerosis prevention and treatment}

Atherosclerosis, a chronic progression from very early stage [2], inflammatory, cholesterol-rich lipids piling up disease, can principal morbidity and mortality worldwide [81]. Main therapeutic strategy to lower or reverse atherosclerosis is statins, but the clinical benefits of statins is somehow limited [82]. Surprisingly, recent reports have mentioned that treatment of statins can improve the $\mathrm{H}_{2} \mathrm{~S}$ production, but it is the lipophilic atorvastatin, but not the hydrophilic pravastatin that increases the net $\mathrm{H}_{2} \mathrm{~S}$ production [83-88]. Recently, It is reported that estrogen evoked anti-atherosclerotic effects was mediated through CSEgenerated $\mathrm{H}_{2} \mathrm{~S}$ [89]. Meanwhile, $\mathrm{H}_{2} \mathrm{~S}$ has been proved to protect arteries from atherogenesis via various mechanisms.

Evidence has been piling up that $\mathrm{H}_{2} \mathrm{~S}$, a new star of gasotransmitter, plays a significant role in protecting susceptible arteries from atherogenesis via a variety of actions on certain types of cells. Detailed information could be referred to Table 1.

Table 1. $\mathrm{H}_{2} \mathrm{~S}$ exerted therapeutic effects in prevention of atherosclerosis

\begin{tabular}{ll}
\hline Therapeutic effects of $\mathrm{H}_{2} \mathrm{~S}$ & Cell type \\
\hline Dilation, hyperpolarization & $\begin{array}{l}\text { Endothelium [5, 23, 90], VSMCs }[21,24,25,28], \\
\text { nerves [29] }\end{array}$ \\
Redox imbalance $\downarrow$ & $\begin{array}{l}\text { Endothelium [91], VSMCs [51], macrophage, } \\
\text { myocyte [92], brain [93, 94] }\end{array}$ \\
$\begin{array}{l}\text { Angiogenesis-oxygen supply } \uparrow \\
\text { Endothelium [95-97] }\end{array}$ & VSMCs [98, 99] \\
Intimal hyperplasia $\downarrow$ & \\
Apoptosis $\uparrow$ & VSMCs [100] \\
Hypoxia protection $\uparrow$ & VSMCs [101] \\
Senescence $\downarrow$ & embryonic fibroblast [49], endothelium $[68,69]$ \\
Calcification $\downarrow$ & VSMCs [102] \\
Hydroperoxide break down & oxLDL [53], HOCl [103] \\
Platelet aggregation $\downarrow$ & Platelet [104, 105] \\
\hline
\end{tabular}

In vivo evidence of $\mathrm{H}_{2} \mathrm{~S}$ preventing atherosclerosis

Philip K. Moore et al. [106] reported that C57/Bl6 mice fed with a high fat diet up to 16 weeks showed a decrease of $\mathrm{H}_{2} \mathrm{~S}$ producing enzymes which may contribute to later reducing endogenous $\mathrm{H}_{2} \mathrm{~S}$ production and increased levels of plasma IL-6, IL 12p40 and G-CSF, though that of lipid deposition in aortae was inconspicuous and serum amyloid A (SAA) and C-reactive protein (CRP) did not change. CSE down regulation in atherosclerosis may partially attributed by microRNA-186 upregulation in THP-1 macrophages [107]. These evidence indicated that a high fat diet may trigger endogenous $\mathrm{H}_{2} \mathrm{~S}$ production decline which is prior to apparent atherosclerotic disease.

Exogenous $\mathrm{H}_{2} \mathrm{~S}$ treatment in apolipoprotein E (ApoE) knock out (KO) mice inhibits plaque progression. Hart et al. [108] reported that chronic treatment of sodium hydrosulfide in the final 4 weeks of 16 -week high fat diet inhibited the development of vascular lesions and reduced systolic blood pressure whilst protected endothelium via causing reduction in vascular superoxide anion generation. However, inhibiting endogenous $\mathrm{H}_{2} \mathrm{~S}$ generation with DL-propargylglycine (PAG) did not aggravate the lesion progression leading to the result that endogenous $\mathrm{H}_{2} \mathrm{~S}$ is insufficient to abolish the atherogenesis. It is worth mentioning that PAG mediated CSE inhibition came at an incredibly high dosages (e.g., $50 \mathrm{mg} / \mathrm{kg}$ ) and nonspecific effects [109-112].

Other researchers have reported the results in consist with aforementioned protective effects. Plasma $\mathrm{H}_{2} \mathrm{~S}$ decreased and plasma and aortic intercellular adhesion molecule-1 (ICAM-1) increased in ApoE KO mice fed with a high fat diet, while size of atherosclerotic plaque shrank in NaHS treated ApoE KO mice and plaque size increased in ApoE KO mice 
administered with PAG [113]. Besides, NaHS inhibited ICAM-1 expression induced by tumor necrosis factor (TNF)- $\alpha$ stimulation via hampering IKB degradation in HUVECs [113]. Furthermore, Wang et al. [114] suggested that $\mathrm{H}_{2} \mathrm{~S}$ inhibited progression of atherosclerosis in ApoE KO mice with high-fat diet via downregulating CX3CR1 and CX3CL1 expression on macrophages in the lesion plaque in vivo. In addition, exogenous NaHS achieved its beneficial effects on diabetes accelerated atherosclerosis by inducing KEAP1 sulfhydration and NRF2 activation [51]. Interestingly, NaHS exerted its anti-atherosclerosis effects through inducing protein S-nitrosylation [115]. Recent report unveiled that NaHS-induced anti-atherosclerotic effects could also be partially through up-regulating ATP-Binding Cassette Transporter A1 (ABCA1) [116]. In addition to the therapeutic effects of $\mathrm{H}_{2} \mathrm{~S}, \mathrm{H}_{2} \mathrm{~S}$ could be a biomarker for ST-elevation myocardial infarction and unstable angina [117].

Exogenous $\mathrm{H}_{2} \mathrm{~S}$ exerts anti-atherosclerosis effect, but whether exogenous $\mathrm{H}_{2} \mathrm{~S}$ can be physically translated to endogenous $\mathrm{H}_{2} \mathrm{~S}$ in vivo is not clear. Knock out of CSE, CBS or 3-MST may be a feasible approach to estimate the effect of endogenous $\mathrm{H}_{2} \mathrm{~S}$ on tissues and organs. CSE knock out (CSE KO) mice was first reported by Wang et al. and the gene deletion resulted in diminished endothelium-dependent vasorelaxation and profound hypertension [118]. Besides, deficit of CSE led to multiple pathological changes, including VSMCs overproliferation [119], redox imbalances and apoptosis under hypoxia [101], macrophage enhanced releasing of TNF- $\alpha$ induced by oxLDL (CSE knockdown) [120]. Furthermore, Mani et al. [121] reported that early fatty-streak lesions occurred in CSE KO mice fed with an atherogenic paigen-type diet for 12 weeks, together with increased oxidation stress, increased expression of adhesion molecules and exacerbated aortic intimal proliferation. However, wild-type mice fed with an atherogenic paigen-type diet or CSE KO mice fed with a normal chow diet did not develop any distinct atherosclerotic damage. Fed with a regular diet for 24weeks, ApoE KO mice and ApoE $/$ / $\mathrm{CSE}^{-\%}$ (DKO) mice developed atherosclerosis, whereas CSE KO mice and WT mice appeared normal [121]. Though ApoE KO mice and DKO mice shared several similar biomarkers including plasma cholesterol and LDL-cholesterol levels, DKO mice showed an accelerated atherosclerotic plaque rather than CSE KO mice. NaHS intervention reduced the atherosclerotic progress without affecting plasma lipid levels compared with ApoE KO mice, prompting that CSE may be a risk factor independent of plasma lipid homeostasis. Recently, ApoE KO mice overexpressing CSE (Tg/KO) showed an increased $\mathrm{H}_{2} \mathrm{~S}$ generation in aortic tissue, reduced atherosclerotic plaque, alleviated plasma lipid profiles and down-regulated oxidative stress, supporting the assumption that CSE was a plausible approach to prevent atherogenesis [122].

CBS KO mice showed mild and severe homocysteinemia because it is rate-limited enzyme consuming homocysteine to generate precursor of $\mathrm{H}_{2} \mathrm{~S}$. Besides, homozygous mutants suffered from severe growth retardation and the bulk of them died within 5 weeks after birth [123]. The plasma homocysteine level of homozygous and heterozygous mutants was 40 times and 2 times of that of WT mice, respectively. Considering high mortality of homozygous mice, heterozygous mice will be a feasible model for homocysteinemia [123]. In addition to homocysteinemia, CBS KO mice showed an abnormal lipid profiles, including markedly raised triglyceride and nonesterified fatty in serum and liver and serum elevated apolipoprotein B100 and very low density lipoprotein, which may be one of the causable factors of hepatic steatosis [124]. CBS deficit-induced homocysteinemia is involved in various pathogenesis. Hyperhomocysteinemia (HHcy) impairs EDHF induced relaxation in CBS deletion mice small mesenteric arteries by inhibiting SK/IK activities via imbalanced oxidative stress and tyrosine nitration-related mechanisms [125]. By introducing ApoE mutation into CBS $\mathrm{KO}$ mice (ApoE $\mathrm{E}^{-/} / \mathrm{CBS}^{-/}$and $\mathrm{ApoE}^{-/} / \mathrm{CBS}^{+/-}$mice), aortic lesions developed even without dietary manipulation, which indicated endogenous hyperhomocysteinemia was an independent factor for atherogenesis [126]. Interestingly, CBS homozygous mutant mice with zinc-inducible metallothionein promoter (Tg-hCBS) can circumvent the neonatal lethality of homozygous mutants [127]. By crossing ApoE KO mice with Tg-hCBS mice to create the Tg-hCBS ApoE $/ \mathrm{CBS}^{-/}$mice, fed with a high fat diet, severe HHcy exacerbated atherosclerosis and macrophages accumulation in lesions [128]. Additionally, homocysteine 
Fig. 4. NaHS and SPRC, a CSE initiator, significantly improved the MCD diet-induced NAFLD in mice. (A) H\&E staining of liver after scheduled administration. (B) Oil Red-O staining aortas from high fat diet-induced mice model treated with or without NaHS. (C) Pathways involved in prevention of NAFLD of SPRC. (B) is adapted from [116] and (A) and (C) are derived from [136].

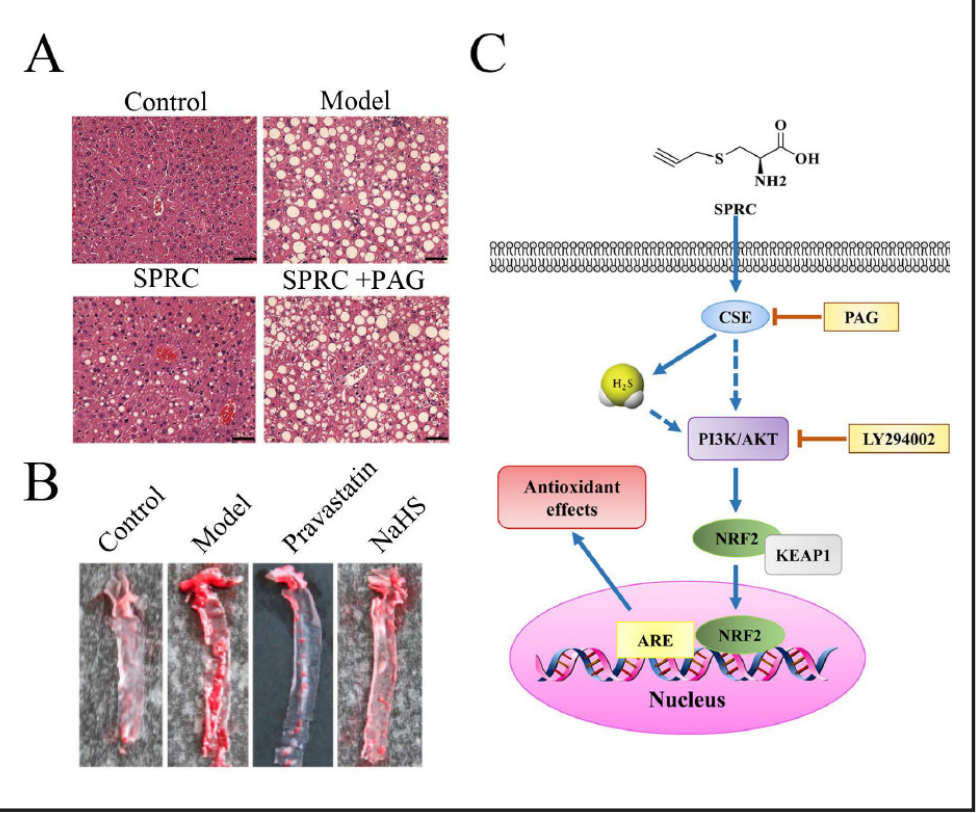

could in turn trigger inflammatory effects through inhibiting CSE expression via DNA hypermethylation on CSE promotor [129].

Introducing endogenous deficiency of $\mathrm{H}_{2} \mathrm{~S}$, whether by knocking out of CSE or CBS,

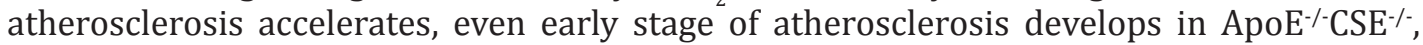

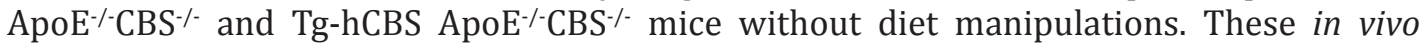
evidence fully stress the importance of endogenous $\mathrm{H}_{2} \mathrm{~S}$ in preventing atherogenesis.

\section{Anti-atherosclerotic effect of $\mathrm{H}_{2} \mathrm{~S}$-releasing drugs}

Considering short half-time period and dramatic blood concentration fluctuation of NaHS, it would be more ideal to apply $\mathrm{H}_{2} \mathrm{~S}$-releasing drugs to circumvent the defects of NaHS. GYY4137 exhibits anti-atherosclerotic effects in high-fat fed ApoE KO mice by downregulating vascular inflammation and oxidative stress, preserving endothelial function and reduced plaque formation achieved. Besides, GYY4137 could protect against myocardial fibrosis [130]. GYY4137 could also dilate arteries [131,132] and attenuate fibrosis of myocytes [130], which might also be implicated in atherosclerosis prevention [51]. S-aspirin (ACS14), another $\mathrm{H}_{2} \mathrm{~S}$-releasing chemical, also protects 12-week high-fat fed ApoE KO mice from atherosclerosis by 12-week treatment of ACS14 via reducing CX3CR1 expression in lesions and impeding atherogenesis and progress of atherosclerosis [133]. ACS14 also inhibits human platelet aggregation [105] and has strong antithrombotic effects [134]. In addition, Diallyl disulfide (DADS), organic sulfide donor which is derived from garlic, abolishes the deleterious effects of ox-LDL on NO production of eNOS [135] and suppresses ox-LDL-induced VCAM-1 and E-selectin expression [136], which may somehow possesses the potential to improve atherosclerosis. Our recent investigation revealed that SPRC could prevent methionine and choline deficient diet-induced fatty liver through antioxidant pathways that were consistent with via which $\mathrm{H}_{2} \mathrm{~S}$ exerted its antiatherosclerotic effects (Fig. 4) [51], and $\mathrm{H}_{2} \mathrm{~S}$ could be promising in preventing atherosclerosis [137].

\section{Conclusion and perspectives}

We have summarized the known knowledge of $\mathrm{H}_{2} \mathrm{~S}$ distribution, production and metabolism, physiological effect and molecular mechanisms related to vasculature, and profound significance of $\mathrm{H}_{2} \mathrm{~S}$ in atherosclerotic progress and development. Finally, we point 
out some additional insights of mechanisms $\mathrm{H}_{2} \mathrm{~S}$ may involve in, shedding new light of how $\mathrm{H}_{2} \mathrm{~S}$ works to protect the precise architecture of the body. Although the full picture of this gas remains to be investigated into and the underlying mechanisms await to be further elucidated, the therapeutic effects of $\mathrm{H}_{2} \mathrm{~S}$ and $\mathrm{H}_{2} \mathrm{~S}$-releasing chemicals are extremely promising. Drawbacks, rapid degradation and dramatic fluctuation, and whether the therapeutic effects in animal studies can be translated into clinical studies require to be considered discreetly. However, a steady $\mathrm{H}_{2} \mathrm{~S}$-releasing donor will be improved, not only for the research purpose but also for the safe and controlled therapeutic application based on $\mathrm{H}_{2} \mathrm{~S}$. In short, a better understanding of how $\mathrm{H}_{2} \mathrm{~S}$ works to protect from atherosclerosis and the development of promising $\mathrm{H}_{2} \mathrm{~S}$-based therapy may pave the way for treating atherosclerosis in the future.

\section{Abbreviations}

$\mathrm{H}_{2} \mathrm{~S}$, hydrogen sulfide; NO, nitric oxide; $\mathrm{CO}$, carbon monoxide; SMC, smooth muscle cell; CSE, cystathionine $\gamma$ lyase; CBS, cystathionine $\beta$ synthase; CAT, cysteine aminotransferase; 3-MST, 3-mercaptopryruvate sulfurtransferase; CL, cysteine lyase; DAO, D-amino acid oxidase; $\mathrm{EDHF}$, endothelium-derived hyperpolarizing factor; $\mathrm{SK}_{\mathrm{Ca}}$ channels, small- conductance calcium-activate potassium channels; $\mathrm{IK}_{\mathrm{Ca}}$ channels, intermediate-conductance calciumactivate potassium channels; $\mathrm{PE}$, phenylephrine; $\mathrm{BK}_{\mathrm{Ca}}$ channels, big-conductance calciumactivated potassium channels; VSMCs, vascular smooth muscle cells; $\mathrm{K}_{\mathrm{ATP}}$ channels, ATPsensitive potassium channels; SUR1,sulfonylurea receptor 1; 4-AP, 4-Aminopyridine; TRPA1, transient receptor potential ankyrin 1; VDCCs, voltage-dependent calcium channels; CaSR, calcium-sensing receptor; phosphodiesterases (PDEs); KEAP1, Kelch-lick ECH-associated protein 1; NRF2, nuclear factor erythroid 2-related factor 2; PGC, proliferator-activated receptor- $\gamma$ coactivator; PPRC, peroxisome proliferator-activated receptor- $\gamma$ coactivatorrelated protein; ox-LDL, oxidized low-density lipoprotein; SAA, serum amyloid A; CRP, C-reactive protein; ApoE, apolipoprotein E; PAG, DL-propargylglycine; ICAM-1, intercellular adhesion molecule-1; TNF, tumor necrosis factor; ABCA1, ATP-Binding Cassette Transporter A1; HHcy, Hyperhomocysteinemia; SIRT1, Sirtuin 1; HUVECs, human umbilical vein endothelial cells; mtDNA, mitochondrial DNA; reactive oxygen species (ROS); DSBs, doublestranded breaks; TFAM, transcription factor A; SPRC, S-Propargyl-Cysteine; KO, knock out; $\mathrm{H}_{2} \mathrm{~S}_{\mathrm{n}}$, polysulfides; NLRP3, nucleotide-binding domain, leucine-rich-containing family, pyrin domaincontaining-3; NOX4, NADPH oxidase 4.

\section{Acknowledgements}

This work was kindly supported by the National Scientific and Technological Major Project (No.2012ZX09501001-001-003, 2012ZX09103101-064), National Natural Science Foundation of China (No. 81573421, 81330080, 81173054), Shanghai Committee of Science and Technology of China (No. 14JC1401100), and the Key Laboratory Program of the Education Commission of Shanghai Municipality (No. ZDSYS14005).

\section{Disclosure Statement}

The authors claim no conflict of interests of the publication of this paper.

\section{References}

1 Wang R: Two's company, three's a crowd: can H2S be the third endogenous gaseous transmitter? FASEB J 2002;16:1792-1798. 


\section{Cellular Physiology Cell Physiol Biochem 2017;42:859-875 \begin{tabular}{l|l} 
DOI: 10.1159/000478628 & O 2017 The Author(s). Published by S. Karger AG, Basel \\
www.karger.com/cpb
\end{tabular}}

Wang et al.: Hydrogen Sulfide Treats Atherosclerosis

2 Randolph GJ: Mechanisms that regulate macrophage burden in atherosclerosis. Circ Res 2014;114:17571771.

3 Shibuya N, Koike S, Tanaka M, Ishigami-Yuasa M, Kimura Y, Ogasawara Y, Fukui K, Nagahara N, Kimura H: A novel pathway for the production of hydrogen sulfide from D-cysteine in mammalian cells. Nat Commun 2013;4:1366.

4 Shibuya N, Kimura H: Production of hydrogen sulfide from d-cysteine and its therapeutic potential. Front Endocrinol (Lausanne) 2013;4:87.

-5 Zhao W, Zhang J, Lu Y, Wang R: The vasorelaxant effect of H(2)S as a novel endogenous gaseous K(ATP) channel opener. EMBO J 2001;20:6008-6016.

-6 Xin H, Wang M, Tang W, Shen Z, Miao L, Wu W, Li C, Wang X, Xin X, Zhu YZ: Hydrogen Sulfide Attenuates Inflammatory Hepcidin by Reducing IL-6 Secretion and Promoting SIRT1-Mediated STAT3 Deacetylation. Antioxid Redox Signal 2016;24:70-83.

7 Li L, Bhatia M, Zhu YZ, Zhu YC, Ramnath RD, Wang ZJ, Anuar FB, Whiteman M, Salto-Tellez M, Moore PK: Hydrogen sulfide is a novel mediator of lipopolysaccharide-induced inflammation in the mouse. FASEB J 2005;19:1196-1198.

8 Fiorucci S, Distrutti E, Cirino G, Wallace JL: The emerging roles of hydrogen sulfide in the gastrointestinal tract and liver. Gastroenterology 2006;131:259-271.

9 Wallace JL, Vong L, McKnight W, Dicay M, Martin GR: Endogenous and exogenous hydrogen sulfide promotes resolution of colitis in rats. Gastroenterology 2009;137:569-578, 578 e561.

10 Martin GR, McKnight GW, Dicay MS, Coffin CS, Ferraz JG, Wallace JL: Hydrogen sulphide synthesis in the rat and mouse gastrointestinal tract. Dig Liver Dis 2010;42:103-109.

11 Robert K, Vialard F, Thiery E, Toyama K, Sinet PM, Janel N, London J: Expression of the cystathionine beta synthase (CBS) gene during mouse development and immunolocalization in adult brain. J Histochem Cytochem 2003;51:363-371.

12 Teng H, Wu B, Zhao K, Yang G, Wu L, Wang R: Oxygen-sensitive mitochondrial accumulation of cystathionine beta-synthase mediated by Lon protease. Proc Natl Acad Sci U S A 2013;110:12679-12684.

13 Szabo C, Coletta C, Chao C, Modis K, Szczesny B, Papapetropoulos A, Hellmich MR: Tumor-derived hydrogen sulfide, produced by cystathionine-beta-synthase, stimulates bioenergetics, cell proliferation, and angiogenesis in colon cancer. Proc Natl Acad Sci U S A 2013;110:12474-12479.

14 Mani S, Untereiner A, Wu L, Wang R: Hydrogen sulfide and the pathogenesis of atherosclerosis. Antioxid Redox Signal 2014;20:805-817.

15 Nagahara N, Ito T, Kitamura H, Nishino T: Tissue and subcellular distribution of mercaptopyruvate sulfurtransferase in the rat: confocal laser fluorescence and immunoelectron microscopic studies combined with biochemical analysis. Histochem Cell Biol 1998;110:243-250.

-16 Shibuya N, Mikami Y, Kimura Y, Nagahara N, Kimura H: Vascular endothelium expresses 3-mercaptopyruvate sulfurtransferase and produces hydrogen sulfide. J Biochem 2009;146:623-626.

17 Kuo MM, Kim DH, Jandu S, Bergman Y, Tan S, Wang H, Pandey DR, Abraham TP, Shoukas AA, Berkowitz DE, Santhanam L: MPST but not CSE is the primary regulator of hydrogen sulfide production and function in the coronary artery. Am J Physiol Heart Circ Physiol 2016;310:H71-79.

18 Modis K, Panopoulos P, Coletta C, Papapetropoulos A, Szabo C: Hydrogen sulfide-mediated stimulation of mitochondrial electron transport involves inhibition of the mitochondrial phosphodiesterase 2A, elevation of cAMP and activation of protein kinase A. Biochem Pharmacol 2013;86:1311-1319.

19 Wallace JL, Wang R: Hydrogen sulfide-based therapeutics: exploiting a unique but ubiquitous gasotransmitter. Nat Rev Drug Discov 2015;14:329-345.

20 Mustafa AK, Sikka G, Gazi SK, Steppan J, Jung SM, Bhunia AK, Barodka VM, Gazi FK, Barrow RK, Wang R, Amzel LM, Berkowitz DE, Snyder SH: Hydrogen sulfide as endothelium-derived hyperpolarizing factor sulfhydrates potassium channels. Circ Res 2011;109:1259-1268.

21 Tang G, Yang G, Jiang B, Ju Y, Wu L, Wang R: H(2)S is an endothelium-derived hyperpolarizing factor. Antioxid Redox Signal 2013;19:1634-1646.

22 Jackson-Weaver O, Paredes DA, Gonzalez Bosc LV, Walker BR, Kanagy NL: Intermittent hypoxia in rats increases myogenic tone through loss of hydrogen sulfide activation of large-conductance $\mathrm{Ca}(2+)$-activated potassium channels. Circ Res 2011;108:1439-1447. 


\section{Cellular Physiology Cell Physiol Biochem 2017;42:859-875 \begin{tabular}{l|l} 
DOI: 10.1159/000478628 & $\begin{array}{l}\text { O 2017 The Author(s). Published by S. Karger AG, Basel } \\
\text { www.karger.com/cpb }\end{array}$ \\
\hline and Biochemistry
\end{tabular}}

Wang et al.: Hydrogen Sulfide Treats Atherosclerosis

23 Jackson-Weaver O, Osmond JM, Riddle MA, Naik JS, Gonzalez Bosc LV, Walker BR, Kanagy NL: Hydrogen sulfide dilates rat mesenteric arteries by activating endothelial large-conductance $\mathrm{Ca}(2)(+)$-activated $\mathrm{K}(+)$ channels and smooth muscle Ca(2)(+) sparks. Am J Physiol Heart Circ Physiol 2013;304:H1446-1454.

24 Cheng Y, Ndisang JF, Tang G, Cao K, Wang R: Hydrogen sulfide-induced relaxation of resistance mesenteric artery beds of rats. Am J Physiol Heart Circ Physiol 2004;287:H2316-2323.

25 Tang G, Wu L, Liang W, Wang R: Direct stimulation of K(ATP) channels by exogenous and endogenous hydrogen sulfide in vascular smooth muscle cells. Mol Pharmacol 2005;68:1757-1764.

26 Jiang B, Tang G, Cao K, Wu L, Wang R: Molecular mechanism for H(2)S-induced activation of K(ATP) channels. Antioxid Redox Signal 2010;12:1167-1178.

-27 Gade AR, Kang M, Akbarali HI: Hydrogen sulfide as an allosteric modulator of ATP-sensitive potassium channels in colonic inflammation. Mol Pharmacol 2013;83:294-306.

28 Cheang WS, Wong WT, Shen B, Lau CW, Tian XY, Tsang SY, Yao X, Chen ZY, Huang Y: 4-aminopyridinesensitive $\mathrm{K}+$ channels contributes to NaHS-induced membrane hyperpolarization and relaxation in the rat coronary artery. Vascul Pharmacol 2010;53:94-98.

29 White BJ, Smith PA, Dunn WR: Hydrogen sulphide-mediated vasodilatation involves the release of neurotransmitters from sensory nerves in pressurized mesenteric small arteries isolated from rats. $\mathrm{Br} \mathrm{J}$ Pharmacol 2013;168:785-793.

30 Miyamoto R, Koike S, Takano Y, Shibuya N, Kimura Y, Hanaoka K, Urano Y, Ogasawara Y, Kimura H: Polysulfides (H2Sn) produced from the interaction of hydrogen sulfide (H2S) and nitric oxide (NO) activate TRPA1 channels. Sci Rep 2017;7:45995.

-31 Wu D, Hu Q, Ma F, Zhu YZ: Vasorelaxant Effect of a New Hydrogen Sulfide-Nitric Oxide Conjugated Donor in Isolated Rat Aortic Rings through cGMP Pathway. Oxid Med Cell Longev 2016;2016:7075682.

- 32 Hu Q, Wu D, Ma F, Yang S, Tan B, Xin H, Gu X, Chen X, Chen S, Mao Y, Zhu YZ: Novel Angiogenic Activity and Molecular Mechanisms of ZYZ-803, a Slow-Releasing Hydrogen Sulfide-Nitric Oxide Hybrid Molecule. Antioxid Redox Signal 2016;25:498-514.

-33 Li XH, Xue WL, Wang MJ, Zhou Y, Zhang CC, Sun C, Zhu L, Liang K, Chen Y, Tao BB, Tan B, Yu B, Zhu YC: H2S regulates endothelial nitric oxide synthase protein stability by promoting microRNA-455-3p expression. Sci Rep 2017;7:44807.

-34 Zhang HX, Liu SJ, Tang XL, Duan GL, Ni X, Zhu XY, Liu YJ, Wang CN: H2S Attenuates LPS-Induced Acute Lung Injury by Reducing Oxidative/Nitrative Stress and Inflammation. Cell Physiol Biochem 2016;40:1603-1612.

35 Moccia F, Bertoni G, Pla AF, Dragoni S, Pupo E, Merlino A, Mancardi D, Munaron L, Tanzi F: Hydrogen sulfide regulates intracellular Ca2+ concentration in endothelial cells from excised rat aorta. Curr Pharm Biotechnol 2011;12:1416-1426.

-36 Bauer CC, Boyle JP, Porter KE, Peers C: Modulation of $\mathrm{Ca}(2+)$ signalling in human vascular endothelial cells by hydrogen sulfide. Atherosclerosis 2010;209:374-380.

37 Pupo E, Pla AF, Avanzato D, Moccia F, Cruz JE, Tanzi F, Merlino A, Mancardi D, Munaron L: Hydrogen sulfide promotes calcium signals and migration in tumor-derived endothelial cells. Free Radic Biol Med 2011;51:1765-1773.

-38 Liang GH, Xi Q, Leffler CW, Jaggar JH: Hydrogen sulfide activates Ca(2)(+) sparks to induce cerebral arteriole dilatation. J Physiol 2012;590:2709-2720.

39 Avanzato D, Merlino A, Porrera S, Wang R, Munaron L, Mancardi D: Role of calcium channels in the protective effect of hydrogen sulfide in rat cardiomyoblasts. Cell Physiol Biochem 2014;33:1205-1214.

-40 Zhong X, Wang Y, Wu J, Sun A, Yang F, Zheng D, Li T, Dong S, Zhao Y, Yang G, Xu C, Sun D, Lu F, Zhang W: Calcium sensing receptor regulating smooth muscle cells proliferation through initiating cystathioninegamma-lyase/hydrogen sulfide pathway in diabetic rat. Cell Physiol Biochem 2015;35:1582-1598.

41 Huang Z, Zhuang X, Xie C, Hu X, Dong X, Guo Y, Li S, Liao X: Exogenous Hydrogen Sulfide Attenuates High Glucose-Induced Cardiotoxicity by Inhibiting NLRP3 Inflammasome Activation by Suppressing TLR4/NFkappaB Pathway in H9c2 Cells. Cell Physiol Biochem 2016;40:1578-1590.

42 Zheng D, Dong S, Li T, Yang F, Yu X, Wu J, Zhong X, Zhao Y, Wang L, Xu C, Lu F, Zhang W: Exogenous Hydrogen Sulfide Attenuates Cardiac Fibrosis Through Reactive Oxygen Species Signal Pathways in Experimental Diabetes Mellitus Models. Cell Physiol Biochem 2015;36:917-929.

-43 Lu M, Liu YH, Ho CY, Tiong CX, Bian JS: Hydrogen sulfide regulates cAMP homeostasis and renin degranulation in As4.1 and rat renin-rich kidney cells. Am J Physiol Cell Physiol 2012;302:C59-66. 


\section{Cellular Physiology Cell Physiol Biochem 2017;42:859-875 \begin{tabular}{l|l} 
DOI: 10.1159/000478628 & $\begin{array}{l}\text { O 2017 The Author(s). Published by S. Karger AG, Basel } \\
\text { www.karger.com/cpb }\end{array}$ \\
\hline
\end{tabular}}

Wang et al.: Hydrogen Sulfide Treats Atherosclerosis

44 Bucci M, Papapetropoulos A, Vellecco V, Zhou Z, Pyriochou A, Roussos C, Roviezzo F, Brancaleone V, Cirino G: Hydrogen sulfide is an endogenous inhibitor of phosphodiesterase activity. Arterioscler Thromb Vasc Biol 2010;30:1998-2004.

45 Wang R: Shared signaling pathways among gasotransmitters. Proc Natl Acad Sci U S A 2012;109:88018802.

46 Mustafa AK, Gadalla MM, Sen N, Kim S, Mu W, Gazi SK, Barrow RK, Yang G, Wang R, Snyder SH: H2S signals through protein S-sulfhydration. Sci Signal 2009;2:ra72.

47 Zhang D, Macinkovic I, Devarie-Baez NO, Pan J, Park CM, Carroll KS, Filipovic MR, Xian M: Detection of protein S-sulfhydration by a tag-switch technique. Angew Chem Int Ed Engl 2014;53:575-581.

-48 Park CM, Macinkovic I, Filipovic MR, Xian M: Use of the "tag-switch" method for the detection of protein S-sulfhydration. Methods Enzymol 2015;555:39-56.

49 Yang G, Zhao K, Ju Y, Mani S, Cao Q, Puukila S, Khaper N, Wu L, Wang R: Hydrogen sulfide protects against cellular senescence via S-sulfhydration of Keap1 and activation of Nrf2. Antioxid Redox Signal 2013;18:1906-1919.

50 Guo C, Liang F, Shah Masood W, Yan X: Hydrogen sulfide protected gastric epithelial cell from ischemia/ reperfusion injury by Keap1 s-sulfhydration, MAPK dependent anti-apoptosis and NF-kappaB dependent anti-inflammation pathway. Eur J Pharmacol 2014;725:70-78.

-51 Xie L, Gu Y, Wen M, Zhao S, Wang W, Ma Y, Meng G, Han Y, Wang Y, Liu G, Moore PK, Wang X, Wang H, Zhang Z, Yu Y, Ferro A, Huang Z, Ji Y: Hydrogen sulfide induces keap1 S-sulfhydration and suppresses diabetesaccelerated atherosclerosis via Nrf2 activation. Diabetes 2016

-52 Yu Q, Lu Z, Tao L, Yang L, Guo Y, Yang Y, Sun X, Ding Q: ROS-Dependent Neuroprotective Effects of NaHS in Ischemia Brain Injury Involves the PARP/AIF Pathway. Cell Physiol Biochem 2015;36:1539-1551.

-53 Muellner MK, Schreier SM, Laggner H, Hermann M, Esterbauer H, Exner M, Gmeiner BM, Kapiotis S: Hydrogen sulfide destroys lipid hydroperoxides in oxidized LDL. Biochem J 2009;420:277-281.

-54 Searcy DG, Whitehead JP, Maroney MJ: Interaction of Cu,Zn superoxide dismutase with hydrogen sulfide. Arch Biochem Biophys 1995;318:251-263.

-55 Carballal S, Trujillo M, Cuevasanta E, Bartesaghi S, Moller MN, Folkes LK, Garcia-Bereguiain MA, GutierrezMerino C, Wardman P, Denicola A, Radi R, Alvarez B: Reactivity of hydrogen sulfide with peroxynitrite and other oxidants of biological interest. Free Radic Biol Med 2011;50:196-205.

-56 Li Q Lancaster JR, Jr.: Chemical foundations of hydrogen sulfide biology. Nitric Oxide 2013;35:21-34.

57 Potente M, Ghaeni L, Baldessari D, Mostoslavsky R, Rossig L, Dequiedt F, Haendeler J, Mione M, Dejana E, Alt FW, Zeiher AM, Dimmeler S: SIRT1 controls endothelial angiogenic functions during vascular growth. Genes Dev 2007;21:2644-2658.

-58 Feige JN, Auwerx J: Transcriptional targets of sirtuins in the coordination of mammalian physiology. Curr Opin Cell Biol 2008;20:303-309.

-59 Mattagajasingh I, Kim CS, Naqvi A, Yamamori T, Hoffman TA, Jung SB, DeRicco J, Kasuno K, Irani K: SIRT1 promotes endothelium-dependent vascular relaxation by activating endothelial nitric oxide synthase. Proc Natl Acad Sci U S A 2007;104:14855-14860.

-60 Zhou S, Chen HZ, Wan YZ, Zhang QJ, Wei YS, Huang S, Liu JJ, Lu YB, Zhang ZQ, Yang RF, Zhang R, Cai H, Liu DP, Liang CC: Repression of P66Shc expression by SIRT1 contributes to the prevention of hyperglycemiainduced endothelial dysfunction. Circ Res 2011;109:639-648.

61 Zhang QJ, Wang Z, Chen HZ, Zhou S, Zheng W, Liu G, Wei YS, Cai H, Liu DP, Liang CC: Endothelium-specific overexpression of class III deacetylase SIRT1 decreases atherosclerosis in apolipoprotein E-deficient mice. Cardiovasc Res 2008;80:191-199.

62 Stein S, Lohmann C, Schafer N, Hofmann J, Rohrer L, Besler C, Rothgiesser KM, Becher B, Hottiger MO, Boren J, McBurney MW, Landmesser U, Luscher TF, Matter CM: SIRT1 decreases Lox-1-mediated foam cell formation in atherogenesis. Eur Heart J 2010;31:2301-2309.

63 Wan YZ, Gao P, Zhou S, Zhang ZQ, Hao DL, Lian LS, Li YJ, Chen HZ, Liu DP: SIRT1-mediated epigenetic downregulation of plasminogen activator inhibitor-1 prevents vascular endothelial replicative senescence. Aging Cell 2014;13:890-899.

64 Li L, Zhang HN, Chen HZ, Gao P, Zhu LH, Li HL, Lv X, Zhang QJ, Zhang R, Wang Z, She ZG, Wei YS, Du GH, Liu DP, Liang CC: SIRT1 acts as a modulator of neointima formation following vascular injury in mice. Circ Res 2011;108:1180-1189. 


\section{Cellular Physiology Cell Physiol Biochem 2017;42:859-875 \begin{tabular}{l|l} 
DOI: 10.1159/000478628 & O 2017 The Author(s). Published by S. Karger AG, Basel \\
www.karger.com/cpb
\end{tabular}}

Wang et al.: Hydrogen Sulfide Treats Atherosclerosis

65 Gao P, Xu TT, Lu J, Li L, Xu J, Hao DL, Chen HZ, Liu DP: Overexpression of SIRT1 in vascular smooth muscle cells attenuates angiotensin II-induced vascular remodeling and hypertension in mice. J Mol Med (Berl) 2014;92:347-357.

66 Gorenne I, Kumar S, Gray K, Figg N, Yu H, Mercer J, Bennett M: Vascular smooth muscle cell sirtuin 1 protects against DNA damage and inhibits atherosclerosis. Circulation 2013;127:386-396.

67 Li X, Zhang KY, Zhang P, Chen LX, Wang L, Xie M, Wang CY, Tang XQ: Hydrogen sulfide inhibits formaldehyde-induced endoplasmic reticulum stress in PC12 cells by upregulation of SIRT-1. PLoS One 2014;9:e89856.

-68 Suo R, Zhao ZZ, Tang ZH, Ren Z, Liu X, Liu LS, Wang Z, Tang CK, Wei DH, Jiang ZS: Hydrogen sulfide prevents $\mathrm{H}(2) \mathrm{O}(2)$-induced senescence in human umbilical vein endothelial cells through SIRT1 activation. Mol Med Rep 2013;7:1865-1870.

69 Zheng M, Qiao W, Cui J, Liu L, Liu H, Wang Z, Yan C: Hydrogen sulfide delays nicotinamide-induced premature senescence via upregulation of SIRT1 in human umbilical vein endothelial cells. Mol Cell Biochem 2014;393:59-67.

70 Wu D, Hu Q, Liu X, Pan L, Xiong Q, Zhu YZ: Hydrogen sulfide protects against apoptosis under oxidative stress through SIRT1 pathway in H9c2 cardiomyocytes. Nitric Oxide 2015;46:204-212.

71 Xie L, Feng H, Li S, Meng G, Liu S, Tang X, Ma Y, Han Y, Xiao Y, Gu Y, Shao Y, Park CM, Xian M, Huang Y, Ferro A, Wang R, Moore PK, Wang H, Ji Y: SIRT3 Mediates the Antioxidant Effect of Hydrogen Sulfide in Endothelial Cells. Antioxid Redox Signal 2016;24:329-343.

72 Razani B, Raines EW: Can the DNA damage response be harnessed to modulate atherosclerotic plaque phenotype? Circ Res 2015;116:770-773.

73 Yu E, Calvert PA, Mercer JR, Harrison J, Baker L, Figg NL, Kumar S, Wang JC, Hurst LA, Obaid DR, Logan A, West NE, Clarke MC, Vidal-Puig A, Murphy MP, Bennett MR: Mitochondrial DNA damage can promote atherosclerosis independently of reactive oxygen species through effects on smooth muscle cells and monocytes and correlates with higher-risk plaques in humans. Circulation 2013;128:702-712.

74 Gray K, Kumar S, Figg N, Harrison J, Baker L, Mercer J, Littlewood T, Bennett M: Effects of DNA damage in smooth muscle cells in atherosclerosis. Circ Res 2015;116:816-826.

75 Zhao K, Ju Y, Li S, Altaany Z, Wang R, Yang G: S-sulfhydration of MEK1 leads to PARP-1 activation and DNA damage repair. EMBO Rep 2014;15:792-800.

76 Li S, Yang G: Hydrogen Sulfide Maintains Mitochondrial DNA Replication via Demethylation of TFAM. Antioxid Redox Signal 2015;23:630-642.

77 Rios EC, Szczesny B, Soriano FG, Olah G, Szabo C: Hydrogen sulfide attenuates cytokine production through the modulation of chromatin remodeling. Int J Mol Med 2015;35:1741-1746.

78 Du HP, Li J, You SJ, Wang YL, Wang F, Cao YJ, Hu LF, Liu CF: DNA methylation in cystathionine-gamma-lyase (CSE) gene promoter induced by ox-LDL in macrophages and in apoE knockout mice. Biochem Biophys Res Commun 2016;469:776-782.

79 Feil S, Fehrenbacher B, Lukowski R, Essmann F, Schulze-Osthoff K, Schaller M, Feil R: Transdifferentiation of vascular smooth muscle cells to macrophage-like cells during atherogenesis. Circ Res 2014;115:662667.

80 Wu J, Guo W, Lin SZ, Wang ZJ, Kan JT, Chen SY, Zhu YZ: Gp130-mediated STAT3 activation by S-propargylcysteine, an endogenous hydrogen sulfide initiator, prevents doxorubicin-induced cardiotoxicity. Cell Death Dis 2016;7:e2339.

81 Hodis HN, Mack WJ: Hormone replacement therapy and the association with coronary heart disease and overall mortality: clinical application of the timing hypothesis. J Steroid Biochem Mol Biol 2014;142:68-75.

82 Libby P: Mechanisms of acute coronary syndromes and their implications for therapy. N Engl J Med 2013;368:2004-2013.

83 Wilinski B, Wilinski J, Somogyi E, Piotrowska J, Goralska M: Atorvastatin affects the tissue concentration of hydrogen sulfide in mouse kidneys and other organs. Pharmacol Rep 2011;63:184-188.

84 Wojcicka G, Jamroz-Wisniewska A, Atanasova P, Chaldakov GN, Chylinska-Kula B, Beltowski J: Differential effects of statins on endogenous H2S formation in perivascular adipose tissue. Pharmacol Res 2011;63:6876.

85 Beltowski J, Jamroz-Wisniewska A: Modulation of h(2)s metabolism by statins: a new aspect of cardiovascular pharmacology. Antioxid Redox Signal 2012;17:81-94. 


\section{Cellular Physiology Cell Physiol Biochem 2017;42:859-875 \begin{tabular}{l|l} 
DOI: 10.1159/000478628 & $\begin{array}{l}\text { O 2017 The Author(s). Published by S. Karger AG, Basel } \\
\text { www.karger.com/cpb }\end{array}$
\end{tabular}}

Wang et al.: Hydrogen Sulfide Treats Atherosclerosis

-86 Xu Y, Du HP, Li J, Xu R, Wang YL, You SJ, Liu H, Wang F, Cao YJ, Liu CF, Hu LF: Statins upregulate cystathionine gamma-lyase transcription and $\mathrm{H} 2 \mathrm{~S}$ generation via activating Akt signaling in macrophage. Pharmacol Res 2014;87:18-25.

87 Zhang L, Zhu H, Li M, Gu X: A novel fluorescent probe for imaging endogenous hydrogen sulphide via the CSE enzymatic pathway. Chem Commun (Camb) 2015;51:13135-13137.

88 Zhao C, Zhang X, Li K, Zhu S, Guo Z, Zhang L, Wang F, Fei Q Luo S, Shi P, Tian H, Zhu WH: Forster Resonance Energy Transfer Switchable Self-Assembled Micellar Nanoprobe: Ratiometric Fluorescent Trapping of Endogenous H2S Generation via Fluvastatin-Stimulated Upregulation. J Am Chem Soc 2015;137:84908498.

89 Li H, Mani S, Wu L, Fu M, Shuang T, Xu C, Wang R: The interaction of estrogen and CSE/H2S pathway in the development of atherosclerosis. Am J Physiol Heart Circ Physiol 2017;312:H406-H414.

-90 Ganster F, Burban M, de la Bourdonnaye M, Fizanne L, Douay O, Loufrani L, Mercat A, Cales P, Radermacher P, Henrion D, Asfar P, Meziani F: Effects of hydrogen sulfide on hemodynamics, inflammatory response and oxidative stress during resuscitated hemorrhagic shock in rats. Crit Care 2010;14:R165.

-91 Pan LL, Liu XH, Gong QH, Wu D, Zhu YZ: Hydrogen sulfide attenuated tumor necrosis factor-alpha-induced inflammatory signaling and dysfunction in vascular endothelial cells. PLoS One 2011;6:e19766.

\$2 Xiao J, Zhu X, Kang B, Xu J, Wu L, Hong J, Zhang Y, Ni X, Wang Z: Hydrogen Sulfide Attenuates Myocardial Hypoxia-Reoxygenation Injury by Inhibiting Autophagy via mTOR Activation. Cell Physiol Biochem 2015;37:2444-2453.

93 Wei X, Zhang B, Zhang Y, Li H, Cheng L, Zhao X, Yin J, Wang G: Hydrogen Sulfide Inhalation Improves Neurological Outcome via NF-kappaB-Mediated Inflammatory Pathway in a Rat Model of Cardiac Arrest and Resuscitation. Cell Physiol Biochem 2015;36:1527-1538.

-94 Liu Y, Liao S, Quan H, Lin Y, Li J, Yang Q: Involvement of microRNA-135a-5p in the Protective Effects of Hydrogen Sulfide Against Parkinson's Disease. Cell Physiol Biochem 2016;40:18-26.

-95 Papapetropoulos A, Pyriochou A, Altaany Z, Yang G, Marazioti A, Zhou Z, Jeschke MG, Branski LK, Herndon DN, Wang R, Szabo C: Hydrogen sulfide is an endogenous stimulator of angiogenesis. Proc Natl Acad Sci U S A 2009;106:21972-21977.

-96 Kan J, Guo W, Huang C, Bao G, Zhu Y, Zhu YZ: S-propargyl-cysteine, a novel water-soluble modulator of endogenous hydrogen sulfide, promotes angiogenesis through activation of signal transducer and activator of transcription 3. Antioxid Redox Signal 2014;20:2303-2316.

-97 Tao BB, Liu SY, Zhang CC, Fu W, Cai WJ, Wang Y, Shen Q, Wang MJ, Chen Y, Zhang LJ, Zhu YZ, Zhu YC: VEGFR2 functions as an H2S-targeting receptor protein kinase with its novel Cys1045-Cys1024 disulfide bond serving as a specific molecular switch for hydrogen sulfide actions in vascular endothelial cells. Antioxid Redox Signal 2013;19:448-464.

-98 Yang G, Li H, Tang G, Wu L, Zhao K, Cao Q Xu C, Wang R: Increased neointimal formation in cystathionine gamma-lyase deficient mice: role of hydrogen sulfide in alpha5beta1-integrin and matrix metalloproteinase-2 expression in smooth muscle cells. J Mol Cell Cardiol 2012;52:677-688.

-99 Meng QH, Yang G, Yang W, Jiang B, Wu L, Wang R: Protective effect of hydrogen sulfide on balloon injuryinduced neointima hyperplasia in rat carotid arteries. Am J Pathol 2007;170:1406-1414.

100 Yang G, Wu L, Wang R: Pro-apoptotic effect of endogenous H2S on human aorta smooth muscle cells. FASEB J 2006;20:553-555.

101 Bryan S, Yang G, Wang R, Khaper N: Cystathionine gamma-lyase-deficient smooth muscle cells exhibit redox imbalance and apoptosis under hypoxic stress conditions. Exp Clin Cardiol 2011;16:e36-41.

102 Zavaczki E, Jeney V, Agarwal A, Zarjou A, Oros M, Katko M, Varga Z, Balla G, Balla J: Hydrogen sulfide inhibits the calcification and osteoblastic differentiation of vascular smooth muscle cells. Kidney Int 2011;80:731739.

103 Laggner H, Muellner MK, Schreier S, Sturm B, Hermann M, Exner M, Gmeiner BM, Kapiotis S: Hydrogen sulphide: a novel physiological inhibitor of LDL atherogenic modification by HOCl. Free Radic Res 2007;41:741-747.

104 Zagli G, Patacchini R, Trevisani M, Abbate R, Cinotti S, Gensini GF, Masotti G, Geppetti P: Hydrogen sulfide inhibits human platelet aggregation. Eur J Pharmacol 2007;559:65-68.

105 Gao L, Cheng C, Sparatore A, Zhang H, Wang C: Hydrogen sulfide inhibits human platelet aggregation in vitro in part by interfering gap junction channels: effects of ACS14, a hydrogen sulfide-releasing aspirin. Heart Lung Circ 2015;24:77-85. 


\section{Cellular Physiology Cell Physiol Biochem 2017;42:859-875 \begin{tabular}{ll|l} 
DOI: 10.1159/000478628 & O 2017 The Author(s). Published by S. Karger AG, Basel \\
www.karger.com/cpb
\end{tabular}}

Wang et al.: Hydrogen Sulfide Treats Atherosclerosis

106 Peh MT, Anwar AB, Ng DS, Atan MS, Kumar SD, Moore PK: Effect of feeding a high fat diet on hydrogen sulfide (H2S) metabolism in the mouse. Nitric Oxide 2014;41:138-145.

107 Yao Y, Zhang X, Chen HP, Li L, Xie W, Lan G, Zhao ZW, Zheng XL, Wang ZB, Tang CK: MicroRNA-186 promotes macrophage lipid accumulation and secretion of pro-inflammatory cytokines by targeting cystathionine gamma-lyase in THP-1 macrophages. Atherosclerosis 2016;250:122-132.

108 Ford A, Al-Magableh M, Gaspari TA, Hart JL: Chronic NaHS Treatment Is Vasoprotective in High-Fat-Fed ApoE(-/-) Mice. Int J Vasc Med 2013;2013:915983.

109 Polhemus DJ, Lefer DJ: Emergence of hydrogen sulfide as an endogenous gaseous signaling molecule in cardiovascular disease. Circ Res 2014;114:730-737.

110 Rej R: Aminooxyacetate is not an adequate differential inhibitor of aspartate aminotransferase isoenzymes. Clin Chem 1977;23:1508-1509.

111 Burnett G, Marcotte P, Walsh C: Mechanism-based inactivation of pig heart L-alanine transaminase by L-propargylglycine. Half-site reactivity. J Biol Chem 1980;255:3487-3491.

-112 Ochs RS, Harris RA: Aminooxyacetate inhibits gluconeogenesis by isolated chicken hepatocytes. Biochim Biophys Acta 1980;632:260-269.

113 Wang Y, Zhao X, Jin H, Wei H, Li W, Bu D, Tang X, Ren Y, Tang C, Du J: Role of hydrogen sulfide in the development of atherosclerotic lesions in apolipoprotein E knockout mice. Arterioscler Thromb Vasc Biol 2009;29:173-179.

114 Zhang H, Guo C, Wu D, Zhang A, Gu T, Wang L, Wang C: Hydrogen sulfide inhibits the development of atherosclerosis with suppressing CX3CR1 and CX3CL1 expression. PLoS One 2012;7:e41147.

115 Lin Y, Chen Y, Zhu N, Zhao S, Fan J, Liu E: Hydrogen sulfide inhibits development of atherosclerosis through up-regulating protein S-nitrosylation. Biomed Pharmacother 2016;83:466-476.

116 Li D, Xiong Q, Peng J, Hu B, Li W, Zhu Y, Shen X: Hydrogen Sulfide Up-Regulates the Expression of ATPBinding Cassette Transporter A1 via Promoting Nuclear Translocation of PPARalpha. Int J Mol Sci 2016;17

117 Ali SE, Farag MA, Holvoet P, Hanafi RS, Gad MZ: A Comparative Metabolomics Approach Reveals Early Biomarkers for Metabolic Response to Acute Myocardial Infarction. Sci Rep 2016;6:36359.

118 Yang G, Wu L, Jiang B, Yang W, Qi J, Cao K, Meng Q Mustafa AK, Mu W, Zhang S, Snyder SH, Wang R: H2S as a physiologic vasorelaxant: hypertension in mice with deletion of cystathionine gamma-lyase. Science 2008;322:587-590.

119 Yang G, Wu L, Bryan S, Khaper N, Mani S, Wang R: Cystathionine gamma-lyase deficiency and overproliferation of smooth muscle cells. Cardiovasc Res 2010;86:487-495.

120 Wang XH, Wang F, You SJ, Cao YJ, Cao LD, Han Q, Liu CF, Hu LF: Dysregulation of cystathionine gamma-lyase (CSE)/hydrogen sulfide pathway contributes to ox-LDL-induced inflammation in macrophage. Cell Signal 2013;25:2255-2262.

121 Mani S, Li H, Untereiner A, Wu L, Yang G, Austin RC, Dickhout JG, Lhotak S, Meng QH, Wang R: Decreased endogenous production of hydrogen sulfide accelerates atherosclerosis. Circulation 2013;127:2523-2534.

122 Cheung SH, Kwok WK, To KF, Lau JY: Anti-atherogenic effect of hydrogen sulfide by over-expression of cystathionine gamma-lyase (CSE) gene. PLoS One 2014;9:e113038.

123 Watanabe M, Osada J, Aratani Y, Kluckman K, Reddick R, Malinow MR, Maeda N: Mice deficient in cystathionine beta-synthase: animal models for mild and severe homocyst(e)inemia. Proc Natl Acad Sci U S A 1995;92:1585-1589.

124 Namekata K, Enokido Y, Ishii I, Nagai Y, Harada T, Kimura H: Abnormal lipid metabolism in cystathionine beta-synthase-deficient mice, an animal model for hyperhomocysteinemia. J Biol Chem 2004;279:5296152969.

125 Cheng Z, Jiang X, Kruger WD, Pratico D, Gupta S, Mallilankaraman K, Madesh M, Schafer AI, Durante W, Yang X, Wang H: Hyperhomocysteinemia impairs endothelium-derived hyperpolarizing factor-mediated vasorelaxation in transgenic cystathionine beta synthase-deficient mice. Blood 2011;118:1998-2006.

126 Wang H, Jiang X, Yang F, Gaubatz JW, Ma L, Magera MJ, Yang X, Berger PB, Durante W, Pownall HJ, Schafer AI: Hyperhomocysteinemia accelerates atherosclerosis in cystathionine beta-synthase and apolipoprotein $\mathrm{E}$ double knock-out mice with and without dietary perturbation. Blood 2003;101:3901-3907.

127 Wang L, Jhee KH, Hua X, DiBello PM, Jacobsen DW, Kruger WD: Modulation of cystathionine beta-synthase level regulates total serum homocysteine in mice. Circ Res 2004;94:1318-1324. 


\section{Cellular Physiology Cell Physiol Biochem 2017;42:859-875

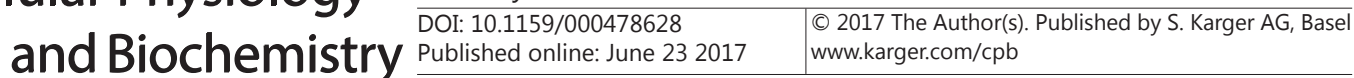

Wang et al.: Hydrogen Sulfide Treats Atherosclerosis

128 Zhang D, Jiang X, Fang P, Yan Y, Song J, Gupta S, Schafer AI, Durante W, Kruger WD, Yang X, Wang H: Hyperhomocysteinemia promotes inflammatory monocyte generation and accelerates atherosclerosis in transgenic cystathionine beta-synthase-deficient mice. Circulation 2009;120:1893-1902.

129 Li JJ, Li Q Du HP, Wang YL, You SJ, Wang F, Xu XS, Cheng J, Cao YJ, Liu CF, Hu LF: Homocysteine Triggers Inflammatory Responses in Macrophages through Inhibiting CSE-H2S Signaling via DNA Hypermethylation of CSE Promoter. Int J Mol Sci 2015;16:12560-12577.

130 Meng G, Zhu J, Xiao Y, Huang Z, Zhang Y, Tang X, Xie L, Chen Y, Shao Y, Ferro A, Wang R, Moore PK, Ji Y: Hydrogen Sulfide Donor GYY4137 Protects against Myocardial Fibrosis. Oxid Med Cell Longev 2015;2015:691070.

131 Li L, Whiteman M, Guan YY, Neo KL, Cheng Y, Lee SW, Zhao Y, Baskar R, Tan CH, Moore PK: Characterization of a novel, water-soluble hydrogen sulfide-releasing molecule (GYY4137): new insights into the biology of hydrogen sulfide. Circulation 2008;117:2351-2360.

132 Chitnis MK, Njie-Mbye YF, Opere CA, Wood ME, Whiteman M, Ohia SE: Pharmacological actions of the slow release hydrogen sulfide donor GYY4137 on phenylephrine-induced tone in isolated bovine ciliary artery. Exp Eye Res 2013;116:350-354.

133 Zhang H, Guo C, Zhang A, Fan Y, Gu T, Wu D, Sparatore A, Wang C: Effect of S-aspirin, a novel hydrogensulfide-releasing aspirin (ACS14), on atherosclerosis in apoE-deficient mice. Eur J Pharmacol 2012;697:106-116.

134 Pircher J, Fochler F, Czermak T, Mannell H, Kraemer BF, Wornle M, Sparatore A, Del Soldato P, Pohl U, Krotz F: Hydrogen sulfide-releasing aspirin derivative ACS14 exerts strong antithrombotic effects in vitro and in vivo. Arterioscler Thromb Vasc Biol 2012;32:2884-2891.

135 Lei YP, Liu CT, Sheen LY, Chen HW, Lii CK: Diallyl disulfide and diallyl trisulfide protect endothelial nitric oxide synthase against damage by oxidized low-density lipoprotein. Mol Nutr Food Res 2010;54:S42-52.

136 Lei YP, Chen HW, Sheen LY, Lii CK: Diallyl disulfide and diallyl trisulfide suppress oxidized LDL-induced vascular cell adhesion molecule and E-selectin expression through protein kinase A- and B-dependent signaling pathways. J Nutr 2008;138:996-1003.

137 Li W, Ma F, Zhang L, Huang Y, Li X, Zhang A, Hou C, Zhu Y: S-Propargyl-cysteine Exerts a Novel Protective Effect on Methionine and Choline Deficient Diet-Induced Fatty Liver via Akt/Nrf2/HO-1 Pathway. Oxid Med Cell Longev 2016;2016:4690857. 